\title{
A Nationalist Backlash to International Refugee Law: Evidence from a Survey Experiment in Turkey
}

\author{
Kevin L. Cope* \& Charles Crabtree ${ }^{\dagger}$
}

June 20, 2018

\begin{abstract}
How do international laws affect citizens' willingness to accept refugees? In full and partial democracies, citizens' attitudes can influence national policy on accepting refugees. A growing literature suggests international institutions can influence citizens' attitudes on foreign policy issues, but those studies are almost entirely confined to domestic human rights and U.S.-based respondents; none consider refugee policy. Using data from a survey experiment administered in September 2017 via face-to-face interviews with 1335 Turkish citizens, we investigate how international norms affect citizens' willingness to accept refugees. Our findings are surprising: reminding people about the government's responsibility under the Refugee Convention to accept refugees triggers a backfire effect, decreasing support for accepting them. This effect appears driven by respondents who support the nationalist-populist incumbent party and by lower-educated respondents. We therefore provide evidence that international refugee law - and perhaps international institutions generally can trigger a political backlash, undermining the very policies that they promote.
\end{abstract}

Keywords: migration, immigration, refugees, experiment

${ }^{*}$ Corresponding author. Research Assistant Professor of Law \& Department of Politics Faculty Affiliate, University of Virginia; Ph.D. Candidate, University of Michigan: kevincope@virginia.edu.

$\dagger^{\dagger}$ Ph.D. Candidate, University of Michigan: ccrabtr@umich.edu. We thank Adam Chilton and Mila Versteeg for their cooperation in designing and fielding our respective surveys. We thank Richard Hynes, Yonatan Lupu, Rebecca Savelsberg, and Shana Tabak for helpful comments. This study was pre-registered with the AEA RCT Registry (AEARCTR-0002439); the pre-analysis plan is available at http://www.socialscienceregistry.org/trials/2439. 


\section{Introduction}

The volume of refugee flows has exploded in recent years. New conflicts in Syria and South Sudan have caused millions to migrate to neighboring countries and across the globe. Ongoing conflicts in Iraq, Libya, the Central African Republic, Sudan, Myanmar, and other places have driven out millions more. The global stock of refugees is now estimated at over 22 million, up from around 10 million just a decade ago. ${ }^{1}$ If some of the predictions on the effect of climate change on sea levels materialize, many more may follow. Massive refugee migrations obviously have enormous humanitarian implications, both for the migrants and the people who stay behind. They also affect the economies, culture, domestic politics, and general welfare of receiving states. For those reasons, the global refugee crisis is increasingly seen as among the biggest challenges for global politics and international cooperation.

The main international set of rules relevant to this crisis is the 1951 Refugee Convention and its 1967 Optional Protocol (the "Refugee Convention"). The Convention requires states to extend certain legal protections to those, who, "owing to a well-founded fear of being persecuted for reasons of race, religion, nationality, membership of a particular social group or political opinion," find themselves outside of their country of nationality. This instrument was drafted with the atrocities of World War II in mind. Critics have since noted its shortcomings in addressing current challenges such as climate change, natural disasters, civil wars, and episodes of gang violence. Most notably, only a small portion of those seeking refuge fall within the Convention's narrow definition of refugee, and the Convention does not require states to provide permanent solutions for refugees, who frequently reside in camps for decades (Goodwin-Gill and McAdam 2007; Martin 2007; Fitzpatrick 1996). Moreover, since protections extend only to those who reach a country's borders, the burden of accepting refugees under the Convention recently has fallen most heavily on nearby states, many of which are ill-equipped to handle them. Countries in the Middle East, Latin America, sub-Saharan Africa, and Southeast Asia have taken the lion's share of refugees, even though many are themselves experiencing conflict or economic distress. Despite these issues, the Refugee Convention is the only major international institution that imposes meaningful obligations on states to aid refugees who reach their shores. ${ }^{2}$

The Refugee Convention is legally binding on states, but its actual power to

\footnotetext{
1 UN High Commissioner for Refugees, Population Statistics Database, available at http: //popstats.unhcr.org/en/overview (last accessed April 29, 2018).

${ }^{2}$ A series of regional instruments within Latin America, Europe, and Africa impose additional rules on participating states, but their scope is limited.
} 
change state behavior is limited by two aspects of international refugee law: it is ill-suited to reciprocity-based enforcement, and no international monitoring body exists to enforce the Convention's terms. The force of many treaties stems largely from one or both of these two features (Guzman 2008). In the absence of these international mechanisms, international refugee law's power to affect state behavior depends largely on domestic legal and political mechanisms, such as judicial sanctions and political mobilization.

A review of recent headlines shows that many countries' political climates are increasingly hostile toward international legal obligations toward refugees. States have found creative ways around those obligations, such as intercepting and turning back refugees at sea or processing them outside the national territory (Goldenziel 2015). In 2015 Hungary began building a razor-wire fence across its border. ${ }^{3}$ Other states have simply begun to flout international law. In 2017, Hungary adopted an accelerated asylum procedure whereby asylum claims could be rejected within a day, ${ }^{4}$ a policy that almost certainly violates the Refugee Convention. ${ }^{5}$ In 2018, the U.S. Department of Justice implemented a policy of criminally prosecuting all would-be immigrants - including asylum-seekers - who cross the U.S.-Mexico border outside designated ports of entry and some asylum-seekers at ports of entry. ${ }^{6} \mathrm{~A}$ primary goal of the policy is ostensibly to discourage refugees (and other migrants without visas) from entering the country, which may violate the Convention. Even Denmark, which was the first state to ratify the Convention, has called for it to be renegotiated entirely if the crises persist. ${ }^{7}$ Meanwhile, right-wing populist parties riding anti-internationalist and anti-immigrant platforms have gained strength in Poland, Austria, the Netherlands, Belgium, Italy, and other countries; many of those officials are calling for state action to stem the flows of refugee flows across their borders.

In this article, we explore popular attitudes towards the Refugee Convention and the extent to which it sways support for admitting refugees. Specifically, we investigate whether support for policies to reduce refugee flows is affected by respondents' being told that these policies violate international law. The motivating assumption

3 “Migrant crisis: Hungary's closed border leaves many stranded.” BBC News, Sept. 15, 2015, available at $\mathrm{http}: / / \mathrm{www} \cdot \mathrm{bbc} . \mathrm{com} /$ news/world-europe-34260071.

4 "The End of the Right to Asylum in Hungary?," The European Database of Asylum Law, May 3, 2017, available at http://www.asylumlawdatabase.eu/en/journal/end-right-asylum-hungary.

5 Steven Simmons, "Hungary Refugee Policy and the Refugee Convention," Mich. ST. InT'L L. REv. LEGAL FORUM (May 23, 2017), available at https://www.msuilr.org/ msuilr-legalforum-blogs/2017/5/23/hungary-refugee-policy-and-the-refugee-convention.

${ }^{6}$ American Civil Liberties Union, MS. L v. ICE, available at urlhttps://www.aclu.org/cases/ms1-v-ice.

7 “Danish PM questions Refugee Convention," Politico EU Edition, Dec. 28, 2015, available at https://www.politico.eu/article/danish-pm-questions-refugee-convention/. 
is that popular support for international law is a key mechanism through which international legal obligations are upheld or violated. If citizens oppose international legal violations, they might successfully pressure democratic governments to avoid those violations or punish those that commit them (e.g., Kaempfer and Lowenberg 1992; Rodman 1998). If the public is skeptical or even hostile to international legal constraints, the opposite might happen.

To explore the Refugee Convention's potential impact on support for domestic refugee policy, we fielded a survey experiment in Turkey. ${ }^{8}$ Turkey is a good place to study the effect of international law on domestic refugee policy for several reasons. Its political climate differs significantly from that of the United States, where all but one experimental study on international law's influence on public opinion have been fielded. Turkey has accepted more Syrian refugees (over 3 million) than any other country, and the refugee issue is both contentious and salient among Turks. Turkey combines these large refugee flows with a growing nationalism/antiinternationalism, a trend that has also affected many Western countries. For reasons we explain below, Turkey's international-law obligations toward Syrian refugees are ambiguous, allowing us to leverage that ambiguity to provide alternative experimental treatments that are equally ecologically valid. And critically, despite increasing authoritarianism, Turkey has at least one firm with a recognized record of conducting apolitical, accurate survey research.

Working with that firm, we conducted 1335 face-to-face interviews throughout Turkey in September 2017. To our knowledge, we are the first to examine citizens' willingness to accept refugees using an experimental approach. Moreover, there are no existing studies that explore the Refugee Convention's impact systematically using either experiments or observational data.

Our findings are surprising. Based on prior work, we expected the Refugee Convention to sway popular opinion by decreasing support for initiatives that violate the Convention. Instead, we found the opposite effect: respondents who were told that rejecting refugees would violate international law showed greater support for those anti-refugee initiatives. This result implies a backlash against the Convention, perhaps spurred by a general hostility towards international law. Notably, however, this effect is driven mainly by two types of respondents. The first group comprises supporters of President Erdoğan's nationalist-populist party, the so-called Justice \& Development Party (“Adalet ve Kalkınma Partisi” or “AKP”). The second group comprises lower-educated respondents. Both groups respond to knowledge of the Refugee Convention harshly by indicating increased support for

\footnotetext{
${ }^{8}$ Identifying the causal effect of the Refugee Convention using observation data is fraught with methodological difficulty, including endogeneity problems and selection biases. Survey experiments can overcome many of these challenges.
} 
anti-refugee policies that would violate it.

This article contributes to at least two different bodies of research. First, we add to the growing experimental literature on the effect of international law on popular opinion (Tomz 2008; Wallace 2013, 2014; Chilton 2014). These studies have generally found that respondents are less likely to support policies that violate international law, suggesting that they value international law qua law. Our findings indicate the opposite. While we acknowledge and discuss the possibility that our results are unique to Turkey and/or to international refugee law, it is also possible that they provide a glimpse into a more general challenge to the international legal order: a growing polarization around international law and an increasing opposition among some groups towards international cooperation. Indeed, the only other experimental study on international law to date conducted outside the United States finds a similar backfire effect in Israel (Lupu and Wallace 2017). Further exploration of when international law can backfire is therefore an important avenue for future research.

Second, we expand the research on attitudes towards immigrants. A large body of survey and experimental research over the last two decades has investigated the predictors of citizen preferences for immigration (e.g., Wright, Levy and Citrin 2016; Hainmueller and Hopkins 2015; Sniderman, Hagendoorn and Prior 2004). But this literature has not meaningfully addressed either international law or attitudes towards refugees specifically.

The rest of the article proceeds as follows. Section 2 reviews the literature on international law's effect on public opinion, explaining why past research provides little insight into the international refugee law's impact on attitudes toward refugee policy. Section 3 explains the case selection, research design, data-collection strategy, and methods of analysis. Section 4 discuses our analyses and possible explanations for the findings. Section 5 concludes with suggestions for future research.

\section{Public Opinion and International Law}

\subsection{International Law's Normative Effect on Domestic Policy}

One of the basic insights from democratic theory is that elected leaders respond to popular opinion, albeit to varying degrees. That principle applies even to elected leaders of quasi-democracies and competitive authoritarian regimes, such as Turkey and Russia (Magaloni 2006; Frye, Gehlbach, Marquardt and Reuter 2017; Guriev and Treisman 2015). Popular opinion may have somewhat less impact on foreign relations policy issues, such as whether to go to war (e.g., Saunders 2015). But 
theoretical and empirical research shows that popular opinion can still meaningfully affect state foreign policy, including policy touching on international law (e.g., Kaempfer and Lowenberg 1992; Rodman 1998). Indeed, legislators in some countries routinely frame their arguments over foreign policy in international law terms (Cope 2015). ${ }^{9}$ Assuming popular opinion is relevant to international law compliance, then, where popular opinion turns against practices that violate international legal obligations - either because they are international law or otherwise - fear of electoral repercussions might make governments less likely to pursue those practices themselves, or more likely to punish those that do pursue them.

Popular attitudes about international law are particularly pertinent in areas of international law that lack international enforcement mechanisms, such as reciprocity. Theories of human-rights-treaty effectiveness have therefore looked to domestic politics, including domestic popular opinion, to explain international law's impact (or lack thereof) on state behavior (e.g., Simmons 2009; Lupu 2013, 2015; HafnerBurton 2013; Cope and Creamer 2016). For example, Simmons (2009) emphasizes the role of domestic political mobilization and courts in effectuating human rights treaties. This mobilization is surely more forthcoming and more effective when the public is predisposed toward upholding international law. Moreover, domestic courts sometimes curb government policies that violate international law, and public-law scholars have shown how popular opinion can affect their decisions as well (Dahl 2017; Epstein, Knight and Shvetsova 2001). To the extent internationallaw compliance relies on domestic political and legal mechanisms, then, national popular support for respecting international law is certainly relevant (Chilton 2015).

A recent set of studies has implicitly built on this reasoning, using survey experiments to explore whether and how international law shifts popular opinion. This research has explored some of the explanations about treaty effectiveness that were derived from theory and analysis of observational data. These studies have generally shown that the legal component of international human rights and humanitarian law violations can shift popular opinion. That is, respondents who are told about an immoral state practice are significantly less likely to support that practice (or more likely to support action to prevent it) if they are also told that the practice violates international law (Wallace 2013, 2014; Chilton 2014). These findings are remarkable in their implication that international law qua law can have an observable, normative pull on the electorate. If that in fact occurs, and the electorate pressures leaders into adopting certain policies, international law itself might work through citizens to affect a state's foreign policy.

\footnotetext{
${ }^{9}$ Cope finds that members of the U.S. Congress use the rhetoric of international law in discussing bills that might violate treaties and customary international law in a manner similar to how they use the rhetoric of constitutional law when discussing bills that might violate the U.S. Constitution.
} 


\subsection{Public Opinion and International Refugee Law}

The question of whether international legal commitments can shift popular opinion is therefore relevant for a range of international issues. This is particularly true for international refugee law. The mechanism of state-to-state reciprocity drives compliance in areas like trade, disarmament, and the laws of war (e.g., Morrow 2014,2007 ) but is missing in international refugee law. Indeed, the very terms and logic of refugee law preclude reciprocal enforcement. The Refugee Convention (article 7) explicitly exempts refugees from reciprocity. ${ }^{10} \mathrm{~A}$ key assumption underlying the Convention is that refugees lack protection from persecution in their home country; if a refugee's own state cannot or will not protect its own nationals, it is unlikely to do so for foreigners. Moreover, unlike with relations over war, trade, or other bilateral interactions, there is little practical opportunity for states to engage in reciprocal behavior regarding refugees. States tend to either send or receive significant numbers of refugees within a given period, but not both. (Some notable exceptions include the Democratic Republic of the Congo, Iraq, and Pakistan.) If State B were to eject State A's refugee-nationals in violation of international law, State A would have little opportunity to respond in kind by ejecting nationals of State B, even if it were so inclined or legally permitted by the Refugee Convention.

The Refugee Convention also lacks a centralized enforcement mechanism. It has neither a dedicated inter-governmental organization tasked with information gathering and ensuring compliance nor an individual-complaint procedure (Helfer and Slaughter 1997). The International Court of Justice has jurisdiction over complaints arising under the Convention, but no state has ever filed one. The UN High Commissioner for Refugees has some duties relevant to the Convention such as advising states on their responsibilities, but it has no direct enforcement powers (Pitterman 1985). Together, the lack of reciprocity and international enforcement makes domestic institutions especially important for enforcing refugee law.

Despite this, no existing experimental studies that we know of have considered refugee law; they have dealt almost entirely with international human rights law (e.g., Chilton and Versteeg 2016; Wallace 2013; Putnam and Shapiro 2017) and international humanitarian law (Chilton 2015; Kreps and Wallace 2016). ${ }^{11}$ For example, Wallace (2013) assessed respondents' support for torturing insurgent groups, finding that U.S. respondents who were told it would violate international law were statistically significantly less likely to support it (see also Chilton and Versteeg

\footnotetext{
${ }^{10}$ Article 7 states in part, "After a period of three years' residence, all refugees shall enjoy exemption from legislative reciprocity in the territory of the Contracting States." art. 7, $\mid 2$.

11 Another related study gauged the treatment effect of being told about a trade treaty on U.S. respondents' willingness to cut off trade with Myanmar, in order to promote human rights there (Tomz 2008).
} 
2016). Likewise, respondents told that a foreign state's labor practices violated international law were more likely to support sanctions against that state (Putnam and Shapiro 2017). In the area of international humanitarian law, Chilton (2015) gave U.S. respondents a scenario in which a foreign rebel group was attacking a U.S. ally. The rebels were hiding within civilian populations, and respondents were asked whether they supported bombing the group, thereby putting the civilians at risk. Respondents who were told that the bombings violated international law supported them at slightly lower rates, but so did those who were told the bombings were simply immoral. Similarly, Kreps and Wallace (2016) found that U.S. respondents were less likely to support certain drone strikes if they were told that the United Nations or Human Rights Watch believed the strikes violated international law.

These studies offer valuable insight into how international legal commitments can shift public opinion, but their findings may not generalize to refugee law. It is plausible that the legal nature of international refugee law and the strategic dynamics of its enforcement mean that the Refugee Convention has a very different impact on public opinion from that of human rights treaties and/or international humanitarian law. This is true for two reasons. First, while international human rights law applies to all those in a territory, the majority of those covered by human rights protections are citizens. It is possible that respondents view international refugee law differently because it entails legal obligations owed to "others." That is, while human rights law governs a state's treatment of its own nationals (though it incidentally covers migrants and other non-citizens as well), international refugee law necessarily regulates the treatment of outsiders present in the country or seeking admission. It requires the states to dedicate resources toward outsiders that often have different cultural, ethnic, and religious backgrounds than the state's majority. To the extent citizens accept the legitimacy or normative force of external norms mandating how the government treats them and their fellow nationals, they might be more wary of external norms that protect political strangers in their own country. This is especially true where these norms imply sharing public resources, physical space, and (where refugees have a path to citizenship) political power.

Of course, citizens are not uniformly hostile towards migrants. A large body of observational and experimental research has studied the correlates of citizen preferences for immigrants and immigration. These studies have found that citizens are relatively hostile toward immigration generally, but not uniformly so: different groups have different attitudes, and those attitudes change with conditions inside and outside the country (e.g., Messina 1989). In other words, citizen attitudes are neither exogenous nor static; they turn on phenomena like perceptions of economic security (Wilkes, Guppy and Farris 2008; Kehrberg 2007), personal safety, and un- 
certainty about how immigration policy could affect their standard of living or national culture (Hainmueller and Hopkins 2014; Sniderman, Hagendoorn and Prior 2004). This body of literature thus provides some insights on when people are most likely to shun outsiders seeking admission, including refugees. ${ }^{12}$ Thus far, however, it has not considered whether and how international norms can change such attitudes.

The second reason that the Refugee Convention may affect public opinion differently from rights and humanitarian institutions is that many of the destination countries have seen a rising wave of national-populist sentiment, which might further undermine the Refugee Convention's ability to sway popular opinion. Rightwing populist parties - riding anti-internationalist and anti-immigrant platforms have gained strength in Hungary, Poland, Denmark, Austria, the Netherlands, Belgium, Italy, and other states. The election of Donald Trump in America reflects some of the same sentiments. To some extent, these views are directed at globalist and international institutions generally. ${ }^{13}$ But the national-populist wave also reflects a strong anti-immigrant sentiment, and nationalist-populists have built winning coalitions in part on anti-immigrant campaigns. Hungarian president Victor Orban became more popular among his supporters when he announced plans to build a razor-wire fence on the border. ${ }^{14}$ If the new Italian right-wing coalition were to make good on its election promises, many refugees in Italy might face de-

\footnotetext{
${ }^{12}$ The large body of survey and experimental research that has investigated the predictors of citizen preferences for immigration (e.g., Wright, Levy and Citrin 2016; Hainmueller and Hopkins 2015; Sniderman, Hagendoorn and Prior 2004) comprises two main approaches: political economy, which "commonly views immigration as analogous to international trade[,] ... examin[ing] competition over resources between immigrants and natives," (also called "interests" or rational choice (O'rourke and Sinnott 2006)) and sociopsychological, which emphasizes "group-related attitudes and symbols in shaping immigration attitudes" (also called "ideology" (O'rourke and Sinnott 2006; Hainmueller and Hopkins 2014)). Some studies find a relationship between economic conditions and attitudes toward immigration. Wilkes, Guppy and Farris (2008) find that a weak economy is associated with Canadian citizens' preferring more restriction on immigration (see also Kehrberg 2007). But many scholars argue that explanations based on economic self-interest have relatively little explanatory power (Hainmueller and Hopkins 2014; Sniderman, Hagendoorn and Prior 2004). Instead, the bulk of more recent research suggests that symbolic or ideological concerns, i.e., concerns over "threats to intangible social constructs, such as the national economy or national identity about the nation as a whole," better explain attitudes toward immigrants.

${ }^{13}$ For instance, given the voluntary nature of the Paris Climate Agreement's commitments, President Trump had few rational policy reasons for initiating U.S. withdrawal. But the agreement represents a major face of international global cooperation, which many of his supporters oppose on principle. Some of his supporters may also believe that, as Mr. Trump tweeted in November 2012, "The concept of global warming was created by and for the Chinese in order to make U.S. manufacturing non-competitive." Madeleine Sheehan Perkins \& Rebecca Harrington, "It's 'an expensive hoax' - and other things Trump has said about climate change," BUSINESS INSIDER (June 3, 2017).

${ }^{14}$ See note 3 , supra.
} 
portation. ${ }^{15}$ Of course, nationalism is both a response to liberal refugee policy, and a driver of anti-refugee policy. Threats to personal security often spur a fear and distrust of outsiders, a phenomenon that the sociopsychological literature has observed in several contexts. The recent wave of national populist sentiment is not new; national leaders through history have traded on this phenomenon, leveraging concerns over poverty, safety, and cultural change to spur xenophobia or otherwise enact protectionist immigration policies (or even to drive out existing residents). But nationalism may also affect people's willingness to support international law. Those who buy into nationalist-populist attitudes might be the least supportive of external rules that protect foreign citizens at the perceived expense of citizens.

In some ways, then, this nationalist-populist movement could mean less favorable responses to the Refugee Convention than to international human rights law or international humanitarian law, especially amongst the groups that support these nationalist platforms. ${ }^{16}$ Where public opinion turns against these commitments, governments may become creative in circumventing them. Courts are not immune from popular opinion either, and they may hesitate to obstruct popular sentiment against extending national resources to foreigners.

\section{Research Design}

\subsection{Case Selection}

As we witness a backlash against both international law and immigration in many of the traditional refugee destination countries, can the Refugee Convention sway popular opinion? If so, how? To gain insight into these questions, we fielded a survey experiment about attitudes toward refugees in Turkey.

We chose Turkey for four main reasons. First, one of the major limitations of the experimental literature in international law is that it has almost entirely focused on U.S. respondents; all but one study were fielded in the United States. Given American exceptionalism in international law and internationalism (e.g., Koh 2003), it is unclear to what extent findings about U.S. attitudes toward international law generalize to those from other countries. U.S. political culture has a strong rule-of-law

15 See note 7 , supra.

16 There is a potential counter-veiling force: many of the same destination countries have relatively strong domestic legal systems. In those cases, states implement the obligations of the Refugee Convention in their domestic legal systems. Where ample funding and independent judiciaries exist, states tend to provide due process procedures for securing asylum or other protection from nonrefoulement. This fact may assure that these states are more likely to uphold their international refugee obligations. 
tradition (Gibson 2006), ${ }^{17}$ and it is possible that Americans are more supportive of upholding international commitments (including those that run against their policy interests) (Cope 2015) than respondents in some other countries. Indeed, one poll conducted by World Public Opinion suggests that Americans are among the most supportive of upholding international law, at least in principle. ${ }^{18}$

Indeed, the only published study to date that included non-U.S. respondents also suggests studies based entirely on U.S. respondents may not generalize to other parts of the world. Lupu and Wallace (2017) found a backfire effect of international law among Israeli respondents; those who were told that a government human rights abuse is illegal under international law were actually more likely to support it than those who are told nothing about it. ${ }^{19}$ This finding suggests what other, non-experimental survey research has also found: the normative pull of international law can vary significantly by country, and that we still know relatively little about the impact of international law on popular opinion outside of the United States.

The second reason why Turkey is a desirable forum for this research is that the country is the leading destination for refugees, with nearly 3.1 million Syrians having fled there since the crisis began in 2011. No other country has accepted more from any location. ${ }^{20}$ This means that public attitudes in Turkey toward immigration could matter for those fleeing conflict and persecution elsewhere in the Middle East. We found that Turks were generally knowledgeable about the number of refugees that Turkey had accepted; $72.3 \%$ of respondents knew that the country had received over 3 million Syrian refugees. ${ }^{21}$ Incoming refugees are now subject to a high-profile 2016 agreement with the European Union, which eases EU travel barriers and resumes EU accession talks in exchange for Turkey's accepting additional

\footnotetext{
${ }^{17}$ Gibson (2006) finds, "[S]upport for the rule of law is widespread in the United States[;] ... in comparison to the available evidence from Europe and South Africa, Americans are highly unusual in the degree to which they express support for the rule of law."

18 World Public Opinion, "World Public Opinion on International Law and the World Court," available at http://worldpublicopinion.net/wp-content/uploads/2017/12/WPO_IntlLaw_ Nov09_quaire.pdf (finding that $69 \%$ of Americans agreed more with the statement, "Our nation should consistently follow international laws. It is wrong to violate international laws, just as it is wrong to violate laws within a country" than with the statement, "If our government thinks it is not in our nation's interest, it should not feel obliged to abide by international laws," which was third highest among the twenty-four countries surveyed).

19 Lupu and Wallace (2017) find the expected effect for the same treatment on respondents in India; those who are told the government action violates international law are less likely to support it. They find no evidence of an effect for their Argentinian respondents.

${ }^{20}$ Pakistan, Lebanon, and Jordan are the next most receptive countries, having accepted approximately 2.7 million, 2.2 million, and 1.3 million refugees, respectively.

${ }^{21}$ About another $27 \%$ chose " 1 million-3 million."
} 
refugees. ${ }^{22}$ Some have argued that the recent refugee deal between Turkey and the European Union is critical to the future of the EU, and even liberal democracy in Europe. ${ }^{23}$ Some believe that if the deal were to collapse and another large wave of refugees were to enter the EU, it would help nationalist/anti-EU parties make further gains in European politics. In essence, Turkish attitudes toward refugees have implications not only for Turkish politics and Syrian refugees but for global law and politics generally.

Third, Turkey has been swept up in the nationalist-populist wave of recent years. Many of those who support President Erdoğan do so because of his nationalist agenda. Yet the large number of refugee admissions gives Turkish politics a wrinkle not present in most other states that have taken a nationalist turn. Some have suggested that Erdoğan's unusual openness to Syrian refugees stems from his vision of reviving the past glory of the Ottoman empire or a sense of solidarity with the predominantly Sunni-Muslim population fleeing Syria. Yet the refugee policy has grown unpopular with most Turks. Bowing to public pressure, the Turkish government reportedly returned thousands of Syrians to their country in $2016 .{ }^{24}$ For these reasons, Turkey provides a survey setting with both a strong nationalist-populism (especially among Erdoğan voters) and a substantial number of refugees. These two elements are not present to nearly the same degree in alternative survey venues with large numbers of refugees like the United States, Germany, Hungary, Poland, Jordan, Iraq, and Uganda.

Fourth, there exists some ambiguity about the extent of Turkey's obligations under the Refugee Convention. Turkey ratified the 1967 Optional Protocol (which extends the application of the 1951 Convention both geographically and temporally to include refugees from outside of Europe and for events that took place after 1951) with a reservation that it does not accept the extension of the Convention's

\footnotetext{
${ }^{22}$ The EU-Turkey agreement provides Turkish citizens visa-free travel to the EU, substantial financial assistance to Turkey, and renewed negotiations over Turkey's bid to join the EU. In exchange, among other things, Greece will return to Turkey those irregular migrants and asylumseekers who traveled through Turkey and for whom Turkey is considered a safe country. "EUTurkey migrant deal done," Deutsche Welle (Mar. 18, 2016) available at http://www.dw.com/en/ eu-turkey-migrant-deal-done/a-19127595.

${ }^{23}$ See, e.g.," Newsletter of the European Stability Initiative" (Oct. 11, 2016) ("What happens if the agreement fails? ... [T] he Western Balkans turn into a battleground for migrants, smugglers, border guards, soldiers and vigilante groups, destabilising an already fragile region. And ever larger numbers begin to arrive again in Central Europe. Such a scenario would be a devastating blow to those leaders in Europe who argued that it is possible to have a humane and effective EU policy on border management while respecting the refugee convention.")

24 "Turkey forcibly returned thousands of Syrian refugees to war zone - Amnesty," 4/1/2016, RT, available at https://www.rt.com/news/338011-turkey-syria-refugees-amnesty/. Our survey found that $80.7 \%$ of Turkish respondents generally opposed accepting additional refugees.
} 
geographic scope. ${ }^{25}$ If that reservation is valid, Turkey is obligated to provide protections to refugees from Europe only; it has no legal obligations in the context of the Syrian crisis. Yet such a reservation most certainly undermines the object and purpose of the Convention, and its validity under the law of treaties is therefore uncertain. It is notable that in discussing its obligations under the Convention and in its actual treatment of Syrian refugees seeking entry, Turkey itself has not emphasized the limited geographic scope of its obligations. For that reason, international legal experts can disagree in good faith about whether Turkey must accept Syrian refugees. We leverage this ambiguity by designing a survey experiment that presents participants with two distinct and legally defensible views on international law: that rejecting refugees violates the Convention, and that it does not.

\subsection{Data Sample}

Our population of interest is all adult Turkish citizens. We worked with KONDA Research and Consultancy, a leading Turkish survey research firm with prior experience conducting survey experiments. ${ }^{26}$ KONDA recruited a nationally representative, probability-based sample of Turkish citizens. ${ }^{27}$ The sample was stratified

\footnotetext{
${ }^{25}$ The reservation states, "the Government of Turkey maintains the provisions of the declaration made under [the 1951 Refugee Convention], according to which it applies the Convention only to persons who have become refugees as a result of events occurring in Europe." "Protocol relating to the Status of Refugees," available at https://treaties.un.org/pages/ShowMTDSGDetails.aspx?src= UNTSONLINE\&tabid=2\&mtdsg no=V-5\&chapter=5\&lang=en.

26 KONDA has extensive experience fielding surveys like this, including recruiting representative samples of respondents. Media outlets and research institutes routinely note KONDA's credibility as a polling firm. According to the Middle East Media Research Institute, "KONDA is a reputable polling institute that accurately predicted the AKP victory in July elections almost to the last vote." https://www.memri.org/reports/ memri-news-blog-memri-turkey-blog-memri-iran-blog-memri-economic-blog-visit-daily-0.

According to the Daily Mail, "Konda has built a strong reputation over years for its research on parliamentary elections..." See http://www.dailymail.co.uk/ wires/reuters/article-3092381/Turkish-ruling-party-lose-majority-June-election-poll.

html; see also http://www.independent.co.uk/news/world/middle-east/ turkey-referendum-vote-recep-tayyip-erdogan-win-knife-edge-a7653761.html. And U.S. embassy officials in Turkey have praised KONDA's professionalism and methods. See https://wikileaks.org/plusd/cables/09ISTANBUL180_a.html (noting that "Emre Erdogan noted Konda used good methods and was not influenced by politics. ... The head of Genar Research, M. Teyfik Goksu told us Konda ... strive[s] to conduct sound polling without a political bias ... (SBU) Chairman Agir Dir told us Konda has been conducting scientific polls in Turkey for over two decades, following methods used by American polling firms.").

27 The descriptive statistics of our sample, reported in Appendix A, closely mirror population averages. But even a less representative sample would limit only the generalizability of our findings; our experimental design would still permit us to make valid inferences about the effect of our
} 
based on the population and educational attainment level of neighborhoods and villages. ${ }^{28}$ We collected data on these characteristics from the Address Based Population Registration System (ADNKS) in Turkey, and the results of the November 1, 2015, General Elections in neighborhoods and villages. Following stratification of the sample, 56 neighborhoods and villages were randomly selected. KONDA surveyors then randomly selected and conducted face-to-face interviews with 1,335 respondents from public places across these locations. The survey was fielded throughout Turkey on September 23 and 24, 2017.

Though the recent erosion of free speech protections has made Turks increasingly wary of speaking freely on political questions, this concern is less salient for this survey and for questions about refugees generally. First, the surveyors acquired no contact information or other personally identifying information, so the respondents could be sure that their responses were anonymous. Second, as explained in note 26, supra, KONDA has conducted many other national surveys on contentious political issues in Turkey. Its accurate poll-based predictions of the most recent national election results suggest that respondents felt free to reveal their true political views - including opposition to the current regime - to KONDA pollsters. Moreover, President Erdoğan has strongly supported accepting large numbers of refugees, even though that policy is broadly unpopular. Indeed, the great majority of respondents $(80.7 \%)$ stated that they generally oppose accepting additional refugees. So while social desirability bias (Fisher 1993) and preference falsification (Kuran 1997) are common problems in conducting surveys in authoritarian contexts, we have no reason to believe those issues affected respondent answers in our survey.

Figure 1: Geographic Distribution of Survey Respondents

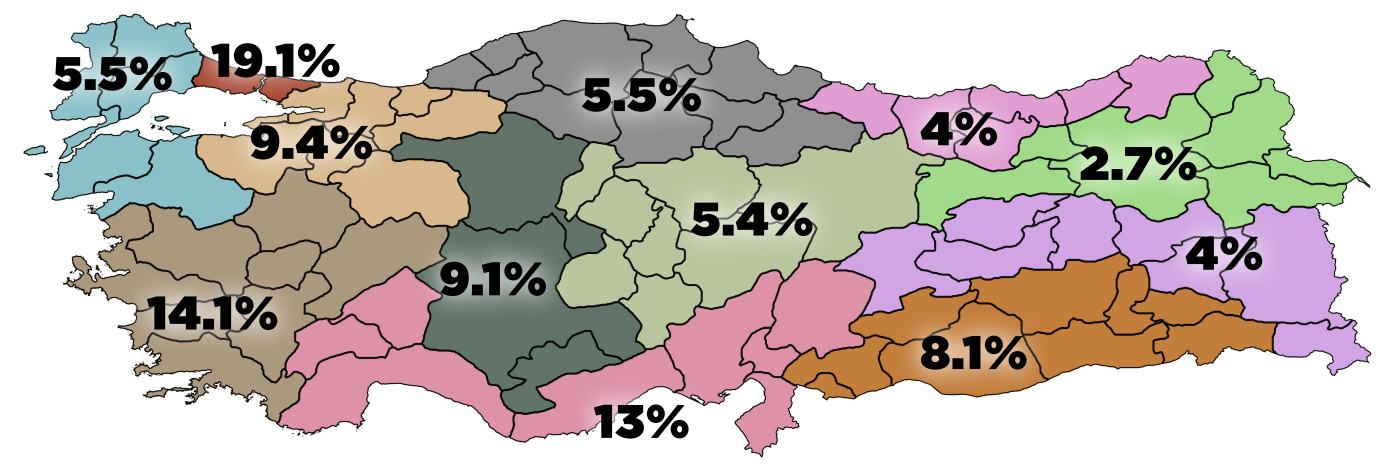

treatments on public opinion for our sample.

${ }^{28}$ Local administrative units were classified as rural, urban, or metropolitan, and the sample was drawn from all 12 Nomenclature of Territorial Units for Statistics (NUTS) regions across Turkey. 
A surveyor error resulted in 1 participant not being assigned to a treatment. 43 subjects did not complete the survey. We drop these 44 individuals from our sample, leaving us with 1,292 participants. ${ }^{29}$

\subsection{Survey Design}

In the first part of the survey, enumerators asked respondents to answer a series of questions about themselves. The first set of questions relates to respondents' demographics and includes gender, age, level of education, religious observance, and the party that they supported in Turkey's most recent parliamentary elections. Participants were also asked about their personal exposure to refugees. In addition to collecting these covariates, surveyors also recorded the region and size of the community where the respondent lived. ${ }^{30}$

In the second part of the survey, enumerators presented respondents with a brief vignette that contained our experimental manipulation. Figure 2 presents the English version of this text. ${ }^{31}$ We used this language for several reasons. One is that we wanted to keep the treatment short, as the survey was conducted during faceto-face interviews. The concern here, voiced by KONDA's representatives, is that some people can lose focus while being read long statements. ${ }^{32}$ Another reason is that we wanted to avoid presenting arguments for and against accepting refugees; these arguments are complicated, and many people in Turkey are familiar with them anyway. For instance, $81.3 \%$ of respondents said they thought that the refugees had had a "bad influence" on the national economy, $12.0 \%$ thought they had either a

\footnotetext{
${ }^{29}$ Dropping the individuals who did not complete the survey might be considered problematic because their attrition could be the result of our experimental cues (Montgomery, Nyhan and Torres 2016). To account for this possible source of bias, we estimate a multinomial logistic regression that treats missing values in our outcome measure as a meaningful response. Our results from this model are substantively similar as those we report below. This provides some evidence that attrition is not a problem for our results.

${ }^{30}$ This part of the survey was combined with another experiment conducted by Chilton and Versteeg. While these two experiments were administered consecutively, they share only some introduction questions and were pre-registered separately. Each treatment version of the first survey contained a one-sentence variation early in the survey about the legality of blocking Wikipedia, which corresponded with one of the refugee-related treatments. The two treatment variations were each ordered randomly and are not substantively related to each other. There is thus no reason to believe that these variations affected the inferences we make about the effect of our randomized cues (Gerber and Green 2012).

31 Appendix B contains the original Turkish version.

${ }^{32}$ Initially, we developed a more richly detailed and nuanced vignette. After KONDA ran a pilot survey, though, the directors determined that some of the respondents lost focus while being read this vignette. This lead them to propose the simpler version provided above. Surveyors provided no evidence that participants wavered in attention while this version was read to them.
} 
"good" influence or "no effect," and just $6.7 \%$ did not know. Including arguments for and against accepting refugees would have dramatically increased the length of the vignette, potentially increasing cognitive demand, and thereby magnifying the risk that the treatment would be lost amidst the other information.

Figure 2: English Translation of Short Paragraph

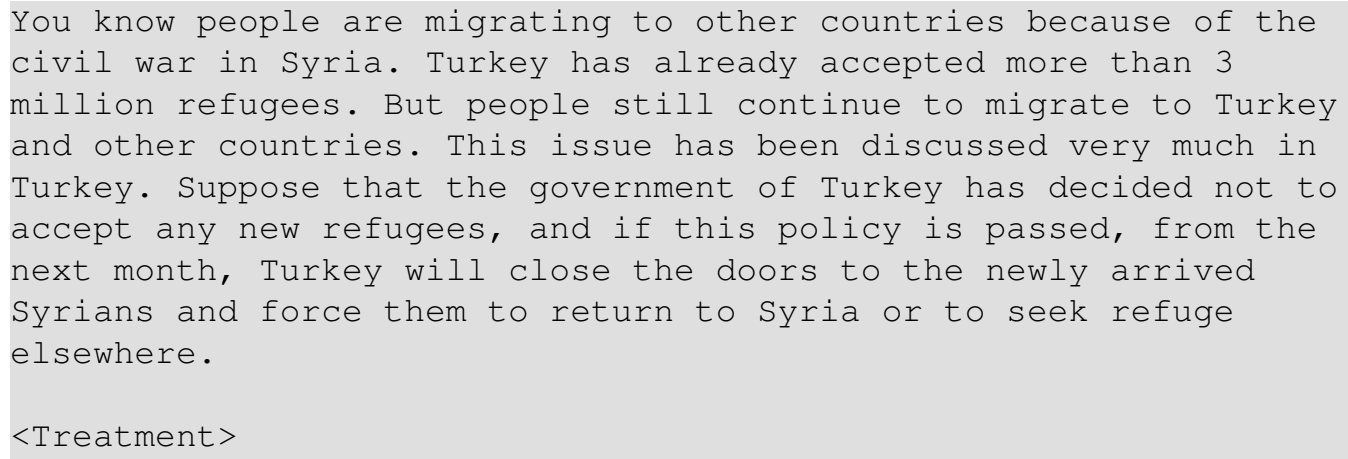

Note: Text in $<>$ represents randomly assigned elements.

To test our hypotheses, we randomly varied the contents of the third paragraph. There were five treatment arms - four treatments and one strict control. They differ only in the extent to which they indicate that international law or norms promote Turkey's continuing to accept refugees. The first version, our control condition, provides no additional information on international laws or norms. The second version indicates that international law requires Turkey to accept refugees; it is intended to test the effect of binding international law on citizens' foreign policy preferences. This treatment would be effective in promoting willingness to accept refugees if and only if respondents view international law as a constraining force - either because they expect that non-compliance will trigger sanctions (through international shaming, ostracizing, economic, or military), because violating it would be immoral, or because its widespread acceptance signals that complying would also be desirable for Turkey. The third version, that Turkey is not obligated under international law to accept all arriving refugees, is (like the second version) intended to test the effect of binding international law on citizens' foreign policy preferences, but in the negative. This treatment would be effective in reducing willingness to accept refugees if and only if respondents view international law as a constraining force, and knowing that it does not constrain shapes their view on the policy for one of the reasons above (sanctions, morality, or signaling). The fourth version, that many other countries have accepted refugees and plan to continue doing so, is intended to test the effect of norms, or people taking some action because others 
are taking it. The fifth version indicates that Turkey is one of many countries that has promised other countries to accept all arriving refugees; it is intended to test the effect of people's valuing upholding international commitments. This treatment is similar to the international law treatment above, but it emphasizes the effect of voluntary, "bottom-up" commitment, as opposed to the "top-down" imposition of rules on a country and its citizens. Table 1 presents all five treatment arms. Treatments were completely randomized, so each participant had an equal probability of receiving any individual treatment.

Table 1: Treatments (English version)

\begin{tabular}{ll}
\hline \hline Treatment & Text \\
\hline 1. CONTROL & [None] \\
2. INTERNATIONAL LAW & $\begin{array}{l}\text { Regardless, Turkey is obligated under in- } \\
\text { ternational law to accept all arriving } \\
\text { refugees in situations like this. } \\
\text { 3. NO INTERNATIONAL LAW } \\
\text { Regardless, Turkey is not obligated un- } \\
\text { der international law to accept all arriving } \\
\text { refugees in situations like this. } \\
\text { Regardless, many countries in the Middle } \\
\text { East- such as Egypt, Lebanon, Jordan- } \\
\text { and many countries in Europe - such as } \\
\text { Germany and Sweden - have collectively } \\
\text { accepted millions of Syrian refugees into } \\
\text { their countries and plan to continue doing } \\
\text { so in the coming years. } \\
\text { Regardless, Turkey is one of many coun- } \\
\text { tries that has promised other countries to } \\
\text { accept all arriving refugees in situations } \\
\text { like this. }\end{array}$ \\
\end{tabular}

Note: Treatments were included in the $<$ Treatment $>$ area of the vignette, as show in Table 2 . Treatments were completely randomized with each participant having an equal probability of receiving any individual treatment.

In the third part of the experiment, we asked what the participants thought about the Turkish government's proposed new policy to start returning refugees. ${ }^{33} \mathrm{We}$ provided respondents with five possible answers that ranged from 'Strongly Support' to 'Strongly Oppose.' Our outcome measure, SUPPORT, is based on how par-

\footnotetext{
33 The English translation of the question language is, "What is your view about the government's proposed new policy to start turning away additional refugees from Syria?"
} 
ticipants replied to this question, with higher values indicating greater agreement. The mean value of SUPPORT on this 5-point scale is 4.13. ${ }^{34}$

The main goal of our research is to gauge how reminding people of Turkey's commitments under the Refugee Convention sways popular opinion. In doing so, we build on the earlier literature surveyed above. Since all but one of the studies there found that reminding respondents of the country's international legal commitments decreased support for violating those commitments, we expected to find similar results in this study (and stated these expectations in our pre-registration ${ }^{35}$ ). At the same time, since we introduce new elements into the research design such as focusing on a new treaty and going outside the United States, it is perhaps not so surprising that our findings diverge from prior studies.

Because we were able to obtain a large sample of respondents, we were able to fine-tune the treatment in two different ways, which allow us to better understand how it is that international law makes a difference. First, we gave some respondents a positive international law treatment (that is, they were told that not taking more refugees violated the Refugee Convention), while others received a negative international law treatment (that is, they were told that not taking more refugees did not violate the Refugee Convention). Doing so allowed us to account for the possibility that the difference between the control group (no statement regarding international norms) and the treatment group (statement of binding international law) may be capturing not international law itself, but the presence of any statement at all. Including a statement of non-bindingness provides a sort of second 'control' that better isolates the effect of the binding international law treatment.

Second, we provide different international treatments associated with different normative mechanisms and varying degrees of formality: from binding law, to "promises" to other countries, to the behavior of other countries. This allows us to isolate the normative effect of law qua law and separate it from other international normative effects, such as the behavior of peer states and the fact that international legal commitments represent promises made on behalf of the country. Each of these mechanisms might exert some form of normative pull. For example, it is possible that people are swayed by an international law treatment not because it is law, but because its legal status leads them to assume that peer states have taken similar actions, a form of herding effect (Goodman and Jinks 2004; Scott and Meyer 1994). Asking about international law and the actions of other countries separately allows

\footnotetext{
${ }^{34}$ Our results are robust to collapsing this ordered variable into an alternative binary measure that is coded 1 if individuals indicate that they strongly or somewhat support the proposed policy change and 0 otherwise.

${ }^{35}$ AEA RCT Registry (AEARCTR-0002439), available at http://www.socialscienceregistry.org/ trials/2439
} 
us to disentangle the effects of those as well. Likewise, it is possible that people are not swayed by international law per se, but because the cue implies that their country has made a voluntary promise, which citizens may feel is important to uphold. Indeed, a substantial body of experimental literature has drawn attention to the importance of promises (Ederer and Stremitzer 2017). Our separate treatments for international law and promises allow us to disentangle these two effects. Especially in a time of growing anti-internationalist sentiments, it is important to understand the mechanisms by which international legal commitments sway the public.

Before analyzing the data, we check the integrity of the randomization procedure by examining whether participant covariates are balanced across treatment groups. We do this in two ways. First, we plot the distributions of the covariates we collected in the first stage of the survey (i.e. age, sex, education, political awareness, and constitutional knowledge) across our treatment groups. Appendix $\mathrm{C}$ contains these figures. We identify no obvious imbalances either through visual inspection or by conducting pair-wise Kolmogorov Smirnov (KS) tests. Second, we compare the log-likelihood statistics of a null model and a full model that regresses the assigned treatment on these covariates (Gerber and Green 2012, 107). We cannot reject the null hypothesis that the full model fits the data better $(p \approx 1)$, which suggests that covariate imbalances are no larger than might occur by chance. This suggests that randomization was 'successful.'

\section{Results and Discussion}

\subsection{Results}

Did our treatments influence participant support for the proposed legislation? To examine this, we estimate an ordinary least squares (OLS) regression model. ${ }^{36}$ Following standard practice, we use HC2 robust standard errors to account for heterogeneity in the error term (Lin and Green 2016). The outcome measure is SUPPORT. On the right-hand side of the equation, we include binary indicators for each of our treatments (except the pure control condition): INTERNATIONAL LAW, No InTERnATIONAL LAW, OTHER COUNTRIES, and Promise. We also include a set of covariates that are plausibly predictive of public support for the government's proposed policy, such as AGE, EdUCATION, and SEX. In addition, we include two

\footnotetext{
36 While our outcome measure is ordered, we use OLS because the results are easy to interpret and because coefficient estimates are unbiased if the model is specified correctly (Lin and Green 2016). Our model is specified correctly since we only include dummy variables for our experimental treatments (Wooldridge 2010). To ensure that our results are not model dependent, we also estimate ordered logit and ordered probit models. The results from these models are substantively the same.
} 
latent measure of respondents' AWARENESS OF CURRENT EvENTS and CONSTITUTIONAL KNOWLEDGE. Finally, we include a measure of partisan support (AKP VOTER), which is coded 1 if the respondent voted for the AKP and 0 otherwise. In line with Lin and Green (2016), we interact our set of treatment indicators, T, with mean-centered versions of these covariates. By doing this, we can interpret the estimated coefficient for each $\mathbf{T}$ as the average effect of assignment to that treatment (Lin and Green 2016).

Figure 3 shows the results of this model, and Appendix D contains the tabular results. The figure plots the estimated coefficients (black points) from the model along with $95 \%$ confidence intervals (black bars). The reference category is the control condition. Contra to our expectations, we see little evidence that our treatments influence SUPPORT. Specifically, we cannot reject the null hypotheses that the No International LaW, Other Countries, and Promise cues have no effect on SUPPORT. This is shown in Figure 3, which indicates that the coefficients for these cues are not statistically significant at conventional levels. Importantly, the estimated effects of NO INTERNATIONAL LAW and PROMISE are also rather small. We offer some possible explanations for the muted effects of these treatments in the discussion section.

We do, however, find mixed support for the effect of INTERNATIONAL LAW. The coefficient on this variable is statistically significant, indicating that reminding participants about Turkey's legal obligation to accept refugees does influence public agreement with the proposed policy. But surprisingly, and contra to our pre-registered expectations, our treatment seems to increase, rather than decrease, support. This is indicated by the positive sign on the estimated coefficient for INTERNATIONAL LAW. Importantly, a Wald test indicates that we can reject the null hypothesis that the effect of the INTERNATIONAL LAW treatment is not different than the effect of the No InTERNATIONAL LAW treatment $(p<0.10)$. The confidence intervals for these coefficients in Figure 3 overlap slightly. However, it is important to remember that overlapping confidence intervals are not necessarily evidence that the differences between point estimates are statistically insignificant. ${ }^{37}$

If this effect were small, we might simply dismiss it as an unusual but substantively meaningless finding. The effect of this treatment, though, is relatively large. On average, participants assigned to this treatment increased their support for the restrictive policy by 0.29 , which is about $\frac{1}{4}$ of a standard deviation in SUPPORT. That we find some effect for our INTERNATIONAL LAW treatment is striking given

\footnotetext{
${ }^{37}$ A separate Wald test indicates that we can also reject the null hypothesis that the effect of the International LAW treatment is not different than the effect of the Promise treatment $(p<$ 0.05). We cannot, however, reject the null hypothesis that the effect of the INTERNATIONAL LAW treatment is not different than the OTHER COUNTRIES treatment $(p>0.29)$.
} 
Figure 3: OLS Results

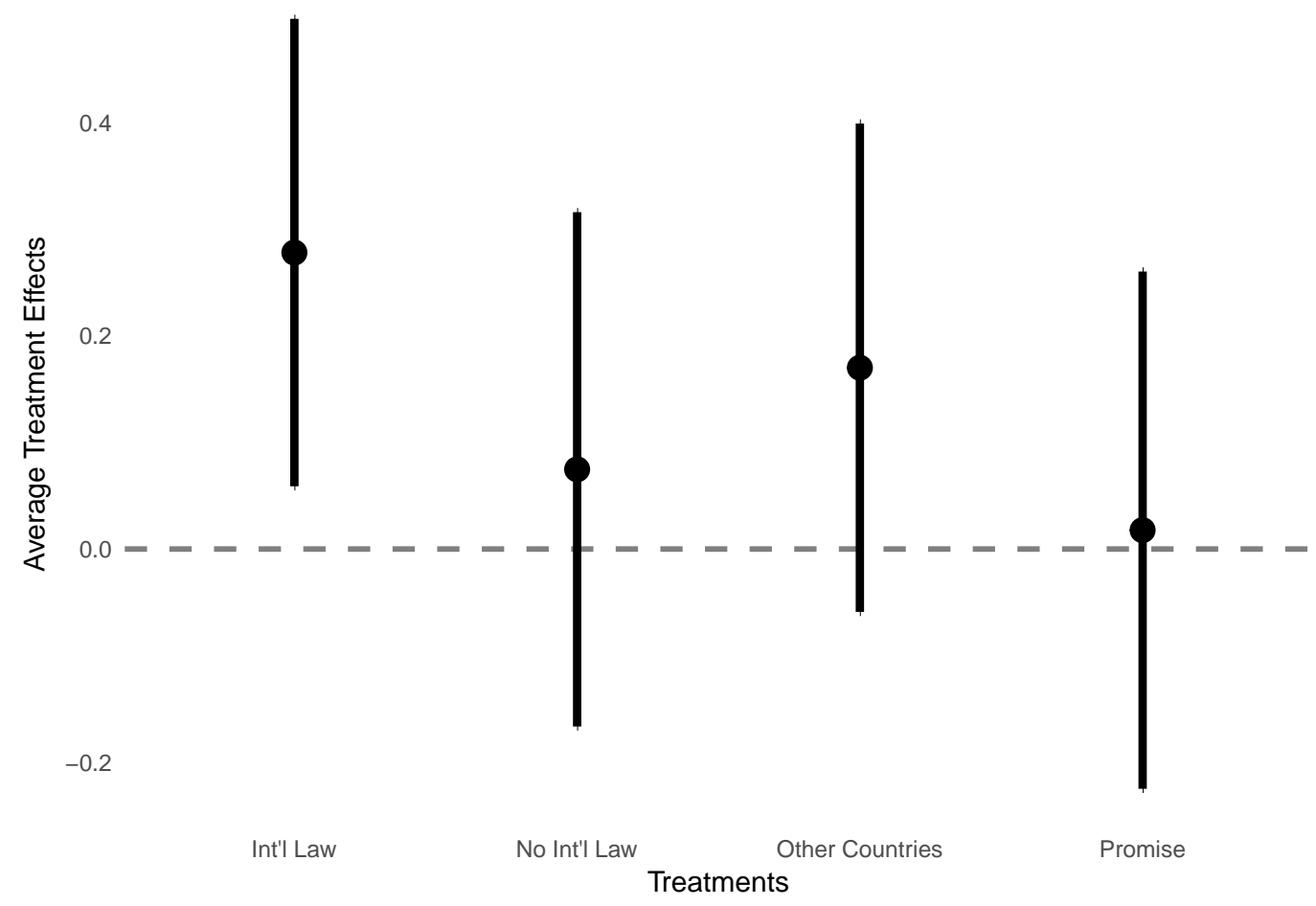

Note: The figure plots the results from an OLS model containing treatment indicators and covariates. Plotted black points indicate estimated coefficients from the model and black bars indicate $95 \%$ confidence intervals. The reference category is the control condition. 
the overall level of SUPPORT on our sample, which could lead to ceiling effects.

\subsection{Exploratory Analyses}

This result presents a new empirical puzzle that we investigate in an exploratory fashion. It is not intuitively obvious why people would more readily support a proposed policy when presented with information that it would violate international law. One explanation is that our finding is a 'statistical fluke.' We therefore conduct a Studentized permutation test (Gerber and Green 2012) to rule out this possibility. The test compares the t-statistics from our OLS model with the "average treatment effect ... under random reassignments of treatment that follow the same randomization scheme as the actual experiment" (Gerber and Green 2012, 117). The $p$-value returned from this test represents the fraction of test statistics strictly greater than the statistic for our sample (Lin and Green 2015). The results from this procedure are very similar to those reported above. ${ }^{38}$ We again find evidence that individuals who are told that Turkey has an international legal obligation to admit refugees are more likely to support the government's proposed policy to stop admitting refugees. ${ }^{39}$

Another possible explanation for this finding is that it might be limited to some subgroups of participants. Specifically, considering that hostility towards international law is common among nationalist parties, it is possible that that the observed effect of the INTERNATIONAL LAW treatment might be driven by party affiliation. Indeed, the initial regression results suggested that the effect of INTERNATIONAL LAW on SUPPORT might be more positive for AKP supporters than opponents. As described above, Erdoğan's AKP has increasingly used nationalist rhetoric and implemented nationalist and authoritarian policies. Around the world, right-wing populism and nationalism are associated with opposition to international institutions and anti-globalization generally. To different degrees, Great Britain's UK Independence Party (UKIP), ${ }^{40}$ France's National Front, Italy's Northern League, and the U.S. Republican Party under Donald Trump ${ }^{41}$ are other examples.

\footnotetext{
38 Since we have a relatively large sample and use robust standard errors, we would expect that they would be in line with our LPM results (Gerber and Green 2012).

39 The results of the permutation test also provide additional evidence that our other treatments do not affect how individuals view Turkey's planned refugee restrictions.

${ }^{40}$ Fintan O'Toole, "Brexit is being driven by English nationalism. And it will end in self-rule," THE GUARDIAN (June 18, 2016), available at https:/www.theguardian.com/commentisfree/2016/ jun/18/england-eu-referendum-brexit.

41 Paul D. Miller, “Trump's Nationalism Is Arbitrary, Dangerous, Incoherent, and Silly," Foreign PoliCY (Jan. 3, 2018), available at http://foreignpolicy.com/2018/01/03/ trumps-nationalism-is-arbitrary-dangerous-incoherent-and-silly/ ("Whatever else U.S. President
} 
To examine this possible moderating relationship, we use a kernel smoothing estimator to compute the marginal effect of INTERNATIONAL LAW on SUPPORT for supporters and opponents of Erdoğan's party. The estimator contains the same independent variables as our OLS model. ${ }^{42}$ We change estimators so that the conditional effect of our international law treatment can vary across the range of our moderator, instead of being fixed on a linear line (Hainmueller, Mummolo and $\mathrm{Xu}$ 2017). ${ }^{43}$ Figure 4 presents our result of interest from this model. The vertical axis denotes the marginal effect of INTERNATIONAL LAW and the horizontal axis denotes levels of AKP VOTER. The black line represents the estimated marginal effect and the gray area around it denotes a 95\% confidence interval band computed from 200 bootstrap runs (Hainmueller, Mummolo and Xu 2017). Above the horizontal axis are two histograms for AKP VOTER. The pink bars represent the values of AKP VOTER for respondents who received the INTERNATIONAL LAW treatment, and the white bars represent the values for individuals assigned to all other treatment groups. As a reminder, we have mean-centered the AKP VOTER variable, which means that the value of 0.6 on the far right of the horizontal axis denotes individuals who supported Erdoğan's party, while the value of -0.4 on the far left denotes individuals who opposed it.

This plot vividly shows that the positive effect of INTERNATIONAL LAW is much higher for respondents who cast ballots for the incumbent party. Indeed, the positive effect is roughly twice as large ( 0.45 compared to 0.23$)$. This difference is equivalent to roughly $\frac{1}{4}$ of a standard deviation in the outcome measure. AKP voters, then, exhibit a much stronger backlash against international law than opponents of the regime.

Another potentially interesting heterogeneous treatment effect might be at work, one driven by the less-educated respondents in our sample. There are at least a couple reasons why this might be the case. First, prior work has shown that feelings of nationalism and education-level are often inversely related, which might mean that backlash is strongest among the less educated. (Golder 2016; Mudde 2007).

Donald Trump has done, he has spent his first year in office continuing and strengthening his commitment to nationalist rhetoric."); “Trump: I Am A Nationalist In A True Sense," RealClear Politics (Feb. 27, 2017), available at https://www.realclearpolitics.com/video/ 2017/02/27/trump_i_am_a_nationalist_in_a_true_sense.html; Elizabeth Bruenig, "Opinion: Trump's solution to America's crisis: Nationalism," WASHINGTON POST (Jan. 30, 2018), available at https://www.washingtonpost.com/opinions/trumps-solution-to-americas-crisis-nationalism/ 2018/01/30/db5f15f4-062f-11e8-94e8-e8b8600ade23_story.html?utm_term=.4e8cc322b43e.

${ }^{42}$ We obtain similar results when we change the outcome measure in our model from the ordered version of SUPPORT to the binary one.

${ }^{43}$ The potential concern here is that by restricting the functional form of the interaction, we might fail to identify the modifying effect of supporting Erdoğan's party (Hainmueller, Mummolo and Xu 2017). 


\section{Figure 4: Marginal Effect of International Law - AKP Voter}

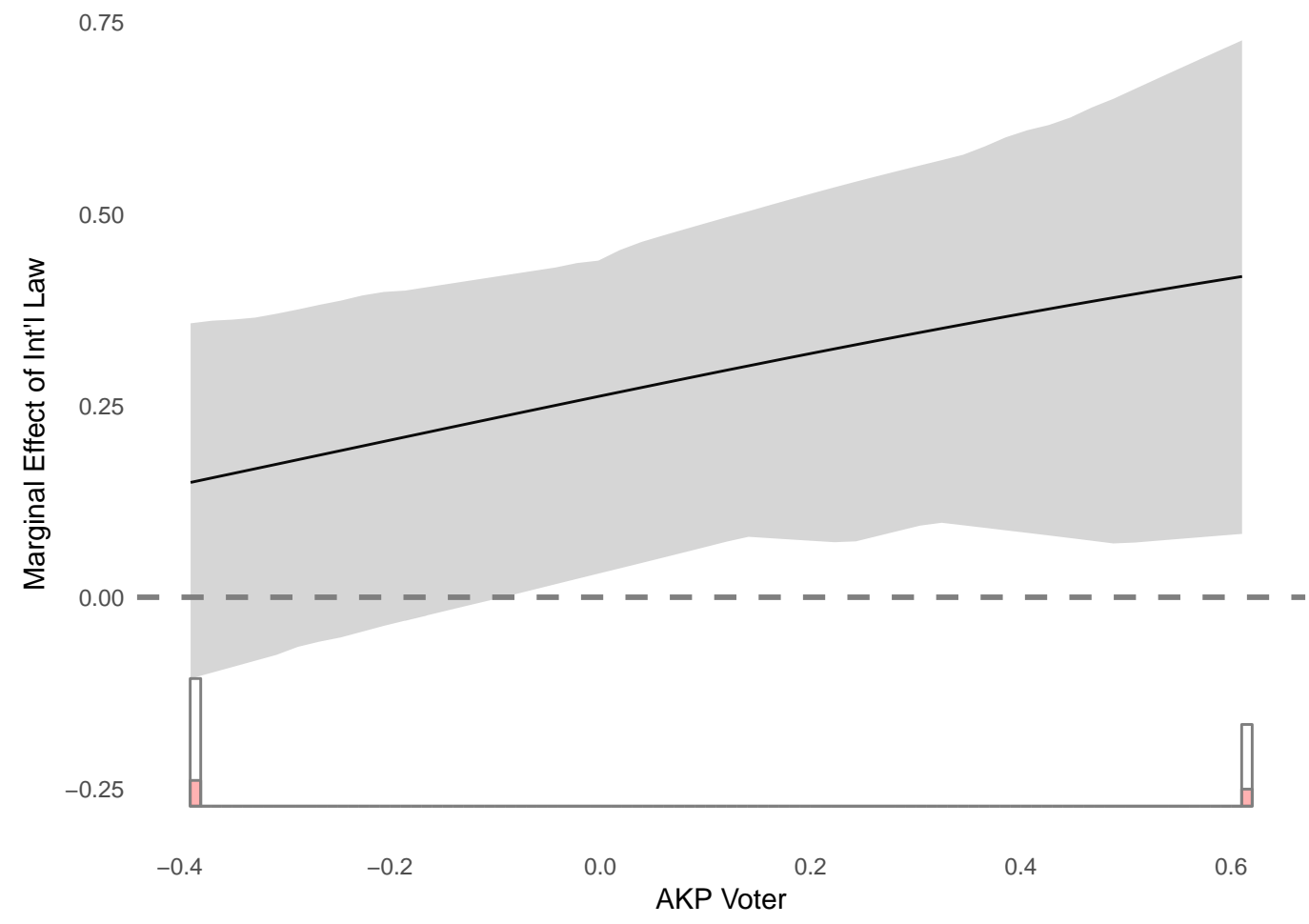

Note: This figure presents the results from a kernel smoothing estimator containing treatment indicators and covariates. The vertical axis denotes the marginal effect of INTERNATIONAL LAW, while the horizontal axis denotes the values of AKP VOTER. The black line represents the estimated marginal effect and the gray area around it denotes a 95\% confidence interval band computed from 200 bootstrap runs. Above the horizontal axis are two histograms for AKP VOTER. The pink bars represent the values of AKP VOTER for respondents who received the INTERNATIONAL LAW treatment, and the white bars represent the values for individuals assigned to all other treatment groups. The value of 0.6 on the far right of the horizontal axis denotes individuals who supported Erdogan's party, while the value of -0.4 on the far left denotes individuals who opposed it. 
Second, individuals with less education may be less likely to understand the consequences of violating international law.

We investigate this potential subgroup variation by revisiting the kernel smoothing estimator described above. This time, we estimate the marginal effect of INTERNATIONAL LAW on SUPPORT across levels of EDUCATION. Figure 5 presents our result of interest from this model. As before, the vertical axis denotes the marginal effect of INTERNATIONAL LAW, but the horizontal axis denotes levels of EDUCATION. The black line represents the estimated marginal effect and the gray area around it denotes a 95\% confidence interval band computed from 200 bootstrap runs (Hainmueller, Mummolo and Xu 2017). Above the horizontal axis are three histograms for EDUCATION. The pink bars represent the values of EDUCATION for respondents who received the INTERNATIONAL LAW treatment and the white bars represent the values for individuals assigned to all other treatment groups. Again, we have mean-centered the EDUCATION variable, which means that the value of 1.5 on the far right of the horizontal axis denotes highly educated individuals, the value of 0.5 in the middle denotes moderately educated individuals, and the value of -0.5 on the far left denotes poorly educated individuals.

The general pattern in this plot supports the idea that our counter-intuitive finding regarding the effect of INTERNATIONAL LAW is partially driven by low-educated respondents. We see that the marginal effect is positive and substantively large for individuals with low levels of education (i.e. less than a high-school degree). Participants in this group respond to the INTERNATIONAL LAW treatment by increasing their support for the government's proposed policy by about 0.42 , or about a $\frac{1}{3}$ of a standard deviation in SUPPORT. While the estimated effect is still positive for individuals with moderate levels of education (i.e. those who completed high school), the marginal effect is about half of that for low-educated respondents. It is also estimated much less precisely. Importantly, the effect is negative for subjects who continued their education past high school, though this effect is also estimated imprecisely. Taken together, though, these marginal effects tell a suggestive story about the role that levels of education play in moderating individual responses to international law. We speculate about the factors driving this relationship in the next section.

Both the party and education-based heterogeneous treatment effect findings suggest the need for additional theorizing about why the public might support domestic policies that ostensibly cut against international law. 
Figure 5: Marginal Effect of International Law - Education

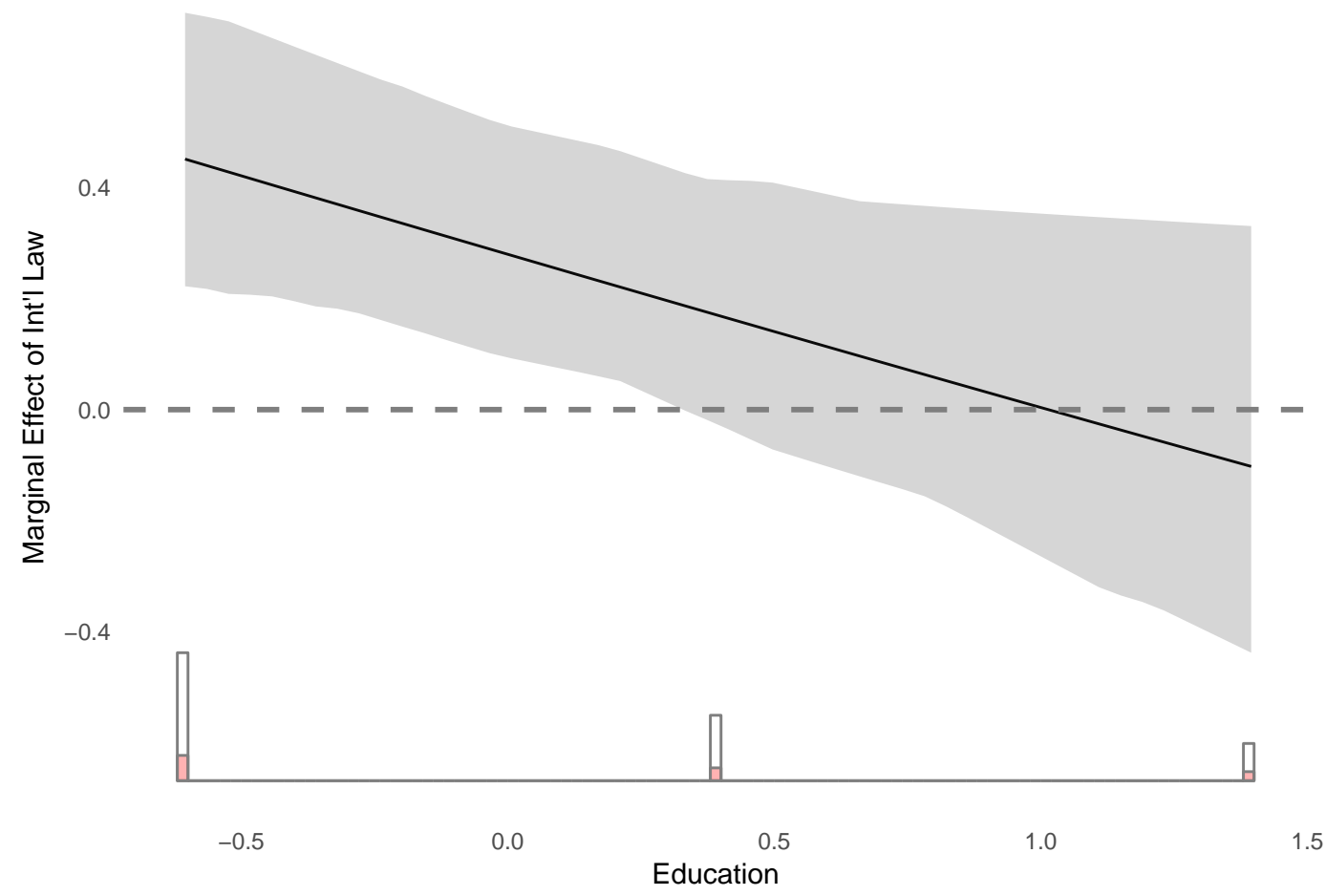

Note: This figure presents the results from a kernel smoothing estimator containing treatment indicators and covariates. The vertical axis denotes the marginal effect of INTERNATIONAL LAW, while the horizontal axis denotes the values of EDUCATION. The black line represents the estimated marginal effect and the gray area around it denotes a 95\% confidence interval band computed from 200 bootstrap runs. Above the horizontal axis are three histograms for EDUCATION. The pink bars represent the values of EDUCATION for respondents who received the INTERNATIONAL LAW treatment and the white bars represent the values for individuals assigned to all other treatment groups. The value of 1.5 on the far right of the horizontal axis denotes highly educated individuals, the value of 0.5 in the middle denotes moderately educated individuals, and the value of -0.5 on the far left denotes poorly educated individuals. 


\subsection{Discussion}

Our finding that the Refugee Convention makes some people more willing to exclude refugees is surprising. At first blush, it is counterintuitive, as it implies that international legal commitments can invoke a negative response, causing people to support the opposite of what international law requires. International law, then, is invoking a backfire effect. Backfire effects have been documented elsewhere in the experimental literature. A number of studies have found that providing individuals with unwelcome information or instructions might create such a backfire effect, encouraging opposition (Fein, McCloskey and Tomlinson 1997; Nyhan and Reifler 2010; Peffley and Hurwitz 2002; Kugler and Cooper 2010). Apparently international law can have the same effect: when international legal commitments are mentioned, they trigger opposition among some respondents. For this backfire effect to exist, international law itself must have been politicized, associated somehow with a certain political ideology. If international law is merely seen as a neutral set of rules and people do not value those rules themselves, it may not sway people one way or the other, but it is unlikely to create a backlash.

What is it about international refugee law in Turkey that generates this negative response? We cannot answer with any certainty, but our study provides some possible explanations. First, it is telling that only the international law treatment generates a backfire effect. Reminding respondents that Turkey promised to take refugees or that peer states have taken refugees does not invoke the same negative sentiment at statistically significant levels; it is only the international law obligation per se that does.

One particularly pertinent question is whether this backfire effect is unique to Turkey. The World Public Opinion survey mentioned above found that, of the nations surveyed, Turks were tied with Iraq for third least supportive for "consistently follow [ing] international laws" even if "it is not in [their] nation's interest." "44 And as we discussed, Turkey has accepted the largest number of Syrian refugees (though not per capita), which may be partially triggering the backlash. But it is unclear why large numbers of refugees would turn public sentiment against international law more than other forces - such as domestic politics - that also promote refugee immigration.

Alternatively, perhaps the fact that this backfire effect is driven by those respondents who support President Erdoğan's AKP party implies that we might find a similar backfire effect in other countries experiencing similar political trends. AKP runs on an increasingly religious and nationalist platform and has shown growing

\footnotetext{
${ }^{44}$ See note 18 , supra.
} 
hostility towards the West. ${ }^{45}$ Non-AKP voters are actually moved in a positive direction, although the effect is not statistically significant. This observation does not reveal what element of the AKP platform causes the negative response, but one possibility is that nationalism itself, or relatedly, anti-internationalism, is the cause. Another option is the party's increased religiosity. Powell and Mitchell (2007) have noted that some principles of Islam, in particular, are at odds with the Westphalian tradition of international law (see also Powell 2015).

As anti-internationalist sentiments are becoming powerful political forces, we may find a similar effect in places with large nationalist-populist movements. In this respect, it is significant that the only other experimental study to date conducted outside the United States (in Argentina, India, and Israel) found a similar backfire effect in Israel. Lupu and Wallace (2017) do not probe this finding in much detail, but they do note the possibility that international law can generate very different sentiments in different settings. Our findings suggest that their results might have been driven by supporters of Benjamin Netanyahu's conservative Israeli Likud party. ${ }^{46}$ If so, we may find a similar backfire effect among French supporters of Marine LePen, Hungarian supporters of Viktor Orbán, Dutch supporters of Geert Wilders, and American supporters of Donald Trump. ${ }^{47}$

\section{Conclusion}

Ours is the first study to explore the impact of the Refugee Convention on popular opinion. Surprisingly, we find evidence of a backlash against the Convention, especially among AKP and less-educated voters. Our analyses raises important questions for future research, most notably, whether our findings are specific to the Refugee Convention or whether they generalize to other instruments of international law. As we noted, the Refugee Convention differs from the human rights agreements featured in previous experimental studies, in that the duties are owed to foreigners, not those with existing legal status in the country. It is possible that this feature makes people more hostile to the Refugee Convention than to other interna-

\footnotetext{
45 Pınar Dinç \& Irem Aydemir, “The EU-Turkey Deal: Ambiguities and Future Scenarios,” LSE Euro Crisis in the Press Blog (Oct. 27, 2016), available at http://blogs.lse.ac.uk/eurocrisispress/ 2016/10/27/the-eu-turkey-deal-ambiguities-and-future-scenarios/ (noting a "rising euro-skepticsm and anti-Westernism in Turkey").

${ }^{46}$ Lupu and Wallace (2017) do not, however, find heterogenous treatment effects based on education. They do not disaggregate based on party affiliation.

${ }^{47}$ One study found that the two personal traits that most accurately predicted support for Donald Trump's presidential candidacy were identifying as supporting authoritarianism and fear of international terrorism (MacWilliams 2016).
} 
tional agreements. Yet, the Turkish case casts doubt on this notion. Specifically, the AKP platform is anti-international but not anti-refugee. That is, while Erdoğan has taken an increasingly nationalist stance, he has also insisted on accepting more Syrian refugees than any other country. This suggests that what drives the backlash is the international legal obligation itself, rather than the fact that the obligation concerns refugees. This is also consistent with Lupu and Wallace's backfire findings in Israel, which did not address refugee law.

It is possible that our backlash findings offer a glimpse into an important emerging challenge for international law. As anti-internationalist sentiments persist in places most relevant to refugee protection, international law may become increasingly polarized, making some more likely to favor policies that violate international law. These are important questions for future research. 


\section{A Appendix}

\section{A.1 Appendix A}

This Appendix provides an overview of the key measures in our analysis. This figure presents histograms for our outcome measure (black bars) and several individuallevel covariates. The vertical axis denotes the observed frequency of variable values. The horizontal axis denotes variable values. The caption below each histogram reports the mean value of the plotted variable and its range, for binary measures, or standard deviation, for all other measures. We use these covariates in our balance tests and mean-centered versions of them in our analyses.

Figure 6: Histograms
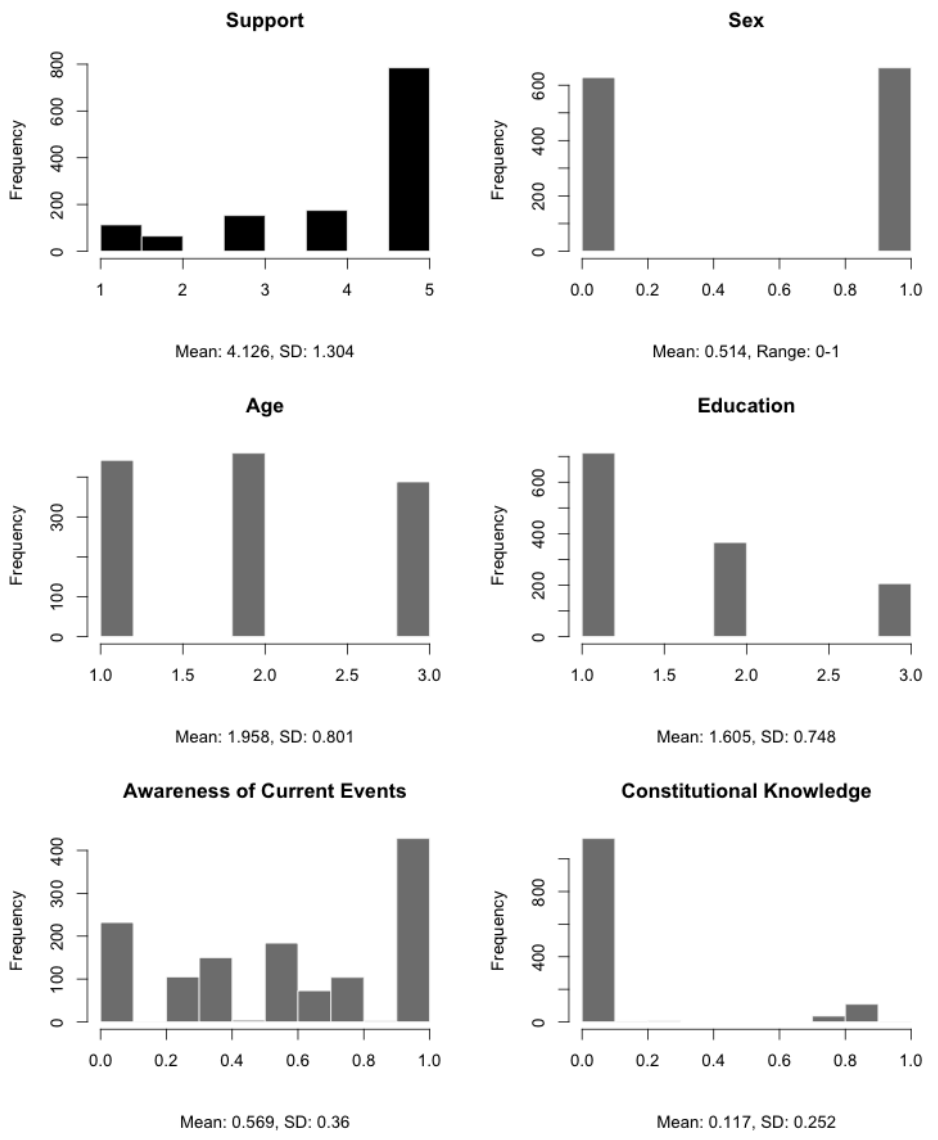


\section{A.2 Appendix B}

This Appendix presents (1) the English-language version of our experimental instrument and (2) its Turkish translation (performed by a Turkish citizen and native Turkish-speaking research assistant, with some edits by Turkish employees of the polling firm, KONDA).

\section{English Version}

As you know, because of the civil war in Syria, people immigrate to other countries. So far, Turkey has accepted more than 3 million refugees. However, the migration continues both to Turkey and other countries. This matter has been very much discussed in Turkey.

\section{SURVEY VERSION 1: None}

SURVEY VERSION 2: Regardless, Turkey is obligated under international law to accept all arriving refugees in situations like this.

SURVEY VERSION 3: Regardless, Turkey is one of many countries that has promised other countries to accept all arriving refugees in situations like this.

SURVEY VERSION 4: Regardless, Turkey is not obligated under international law to accept all arriving refugees in situations like this.

SURVEY VERSION 5: Regardless, many countries in the Middle East - such as Egypt, Lebanon, Jordan - and many countries in Europe — such as Germany and Sweden - have collectively accepted millions of Syrian refugees into their countries and plan to continue doing so in the coming years.

Suppose that the government of Turkey has decided not to accept any new refugees, and if this policy is passed, from the next month, Turkey will close the doors to the newly arrived Syrians and force them to return to Syria or to seek refuge elsewhere.

What is your view about the government's proposed new policy to start turning away additional refugees from Syria?

1. Strongly Support

2. Somewhat Support

3. Neither Support or Oppose

4. Somewhat Oppose

5. Strongly Oppose 


\section{Turkish Version}

Biliyorsunuz Suriye'deki iç savaştan dolayı insanlar başka ülkelere göç ediyor. Türkiye de şimdiye kadär 3 milyondan fazla mülteciyi kabul etti. Ama insanlar hala hem Türkiye'ye hem de başka ülkelere göç etmeye devam ediyor. Bu konu Türkiye'de çok tartışıldı.

\section{ANKET VERSIYYN 1: Yok}

ANKET VERSIYON 2: Her hâlükârda, Türkiye uluslararası hukuka göre, böyle durumlarda, gelen mültecileri kabul etmekle yükümlüdür.

ANKET VERSIYYON 3: Her hâlükârda, Türkiye, böyle durumlarda, gelen mültecileri kabul edeceğini diğer ülkelere taahhöt etmiş olan çok sayıdaki ülkeden biridir.

ANKET VERSIYYN 4: Her hâlükârda, Türkiye uluslararası hukuka göre, böyle durumlarda, gelen tüm mültecileri kabul etmekle yükümlü değildir.

ANKET VERSIYYN 5: Her hâlükârda, Ortadoğu'daki çok sayıda ülke -Mısır, Lübnan, ürdün gibi- ve Avrupa'daki çok sayıda ülke -Almanya ve İsveç gibi- hep birlikte milyonlarca Suriyeliyi ülkelerine kabul ettiler ve ilerleyen yıllarda buna devam etmeyi planlamaktalar.

Farz edin ki Türkiye hükümeti yeni gelecek olan mültecilere kapıları kapatmaya yönelik bir politika hazırlığı içinde. Eğer bu politika hayata geşirilirse, gelecek aydan itibaren, Türkiye yeni gelen Suriyelilere kapıları kapatacak, onları Suriye'ye geri dönmeye veya başka bir yere iltica etmeye mecbur bırakacak.

Hükümetin yeni gelen Suriyelilere kapıları kapatmayı öngören yeni politikası hakkında ne düşünüyorsunuz?

1. Kesinlikle destekliyorum

2. Kismen destekliyorum

3. Ne destekliyorum ne karşıyım

4. Kısmen karşıyım

5. Kesinlikle karşıyım 


\section{A.3 Appendix C}

This Appendix provides some evidence of successful randomization. Figure 7 presents kernel density plots for several individual-level covariates: sex, age, education, awareness, and constitutional knowledge. The horizontal axis denotes variable values. The lines in each plot denote different treatment conditions, as noted in the plot legends. Visual inspection shows that these group distributions appear similar. We formally check for differences between distributions by conducting a set of pair-wise Kolmogorov-Smirnov (KS) tests. The results of these tests suggest that we cannot reject the null that covariate distributions do not differ across treatment groups. 
Figure 7: Kernel Density Plots
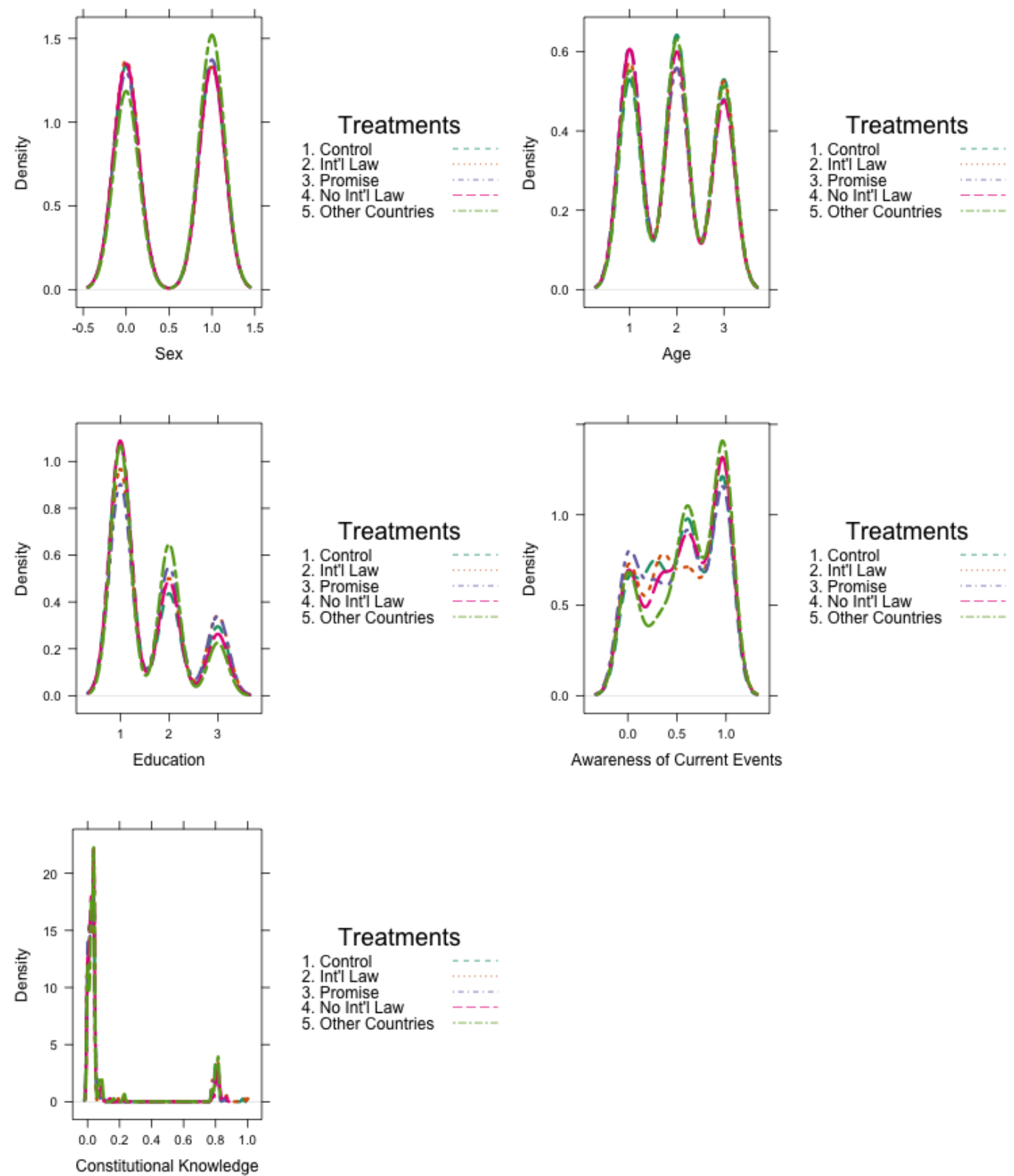

Note: This figure presents kernel density plots for several individual-level covariates: sex, age, education, awareness, and constitutional knowledge. The horizontal axis denotes variable values. The lines in each plot denote different treatment conditions, as noted in the plot legends. 


\section{A.4 Appendix D}

This Appendix provides the tabular results from our OLS model, shown in Table 2. Following standard practice, we use HC2 robust standard errors to account for heterogeneity in the error term (Lin and Green 2016). The outcome measure is SUPPORT. On the right-hand side of the equation, we include binary indicators for each of our treatments (except the pure control condition): INTERNATIONAL LAW, No International Law, Other Countries, and Promise. We also include a set of mean-centered covariates that are plausibly predictive of public support for the government's proposed policy: AgE, EduCATIOn, SEX, AwARENESS OF Current Events, and Constitutional Knowledge. In line with (Lin and Green 2016), we interact our set of treatment indicators, T, with each of these covariates. By doing so, we can interpret the estimated coefficient for each $\mathbf{T}$ as the average effect of assignment to that treatment (Lin and Green 2016).

Table 2: OLS Results

\begin{tabular}{ccc}
\hline \hline Treatment & Coefficient Estimate & Standard Error \\
\hline Int'l Law & 0.278 & 0.112 \\
No Int'l Law & 0.075 & 0.123 \\
Other Countries & 0.170 & 0.117 \\
Promise & 0.018 & 0.124 \\
\hline
\end{tabular}

Note: Table 2 presents the results of our OLS model. Cells contain estimated coefficients and HC2 robust standard errors. The dependent variable is SUPPORT. 


\section{References}

Chilton, Adam S. 2014. "The influence of international human rights agreements on public opinion: An experimental study." Chi. J. Int'l L. 15:110.

Chilton, Adam S. 2015. "The laws of war and public opinion: An experimental study." Journal of Institutional and Theoretical Economics JITE 171(1):181-201.

Chilton, Adam S and Mila Versteeg. 2016. "International law, constitutional law, and public support for torture." Research \& Politics 3(1):2053168016636413.

Cope, Kevin L. 2015. “Congress's International Legal Discourse.” Michigan Law Review 113:7.

Cope, Kevin L., Cope and Cosette Creamer. 2016. "Disaggragating the Human Rights Treaty Regime.” Virginia Journal of International Law .

Dahl, Robert A. 2017. Decision-making in a democracy: The Supreme Court as a national policy-maker. In Constitutionalism and Democracy. Routledge pp. 137154.

Ederer, Florian and Alexander Stremitzer. 2017. "Promises and expectations." Games and Economic Behavior 106:161-178.

Epstein, Lee, Jack Knight and Olga Shvetsova. 2001. "The role of constitutional courts in the establishment and maintenance of democratic systems of government." Law and Society review pp. 117-164.

Fein, Steven, Allison L McCloskey and Thomas M Tomlinson. 1997. "Can the jury disregard that information? The use of suspicion to reduce the prejudicial effects of pretrial publicity and inadmissible testimony." Personality and Social Psychology Bulletin 23(11):1215-1226.

Fisher, Robert J. 1993. "Social desirability bias and the validity of indirect questioning." Journal of consumer research 20(2):303-315.

Fitzpatrick, Joan. 1996. "Revitalizing the 1951 Refugee Convention.” Harv. Hum. Rts. J. 9:229.

Frye, Timothy, Scott Gehlbach, Kyle L Marquardt and Ora John Reuter. 2017. "Is Putin's popularity real?" Post-Soviet Affairs 33(1):1-15.

Gerber, Alan S and Donald P Green. 2012. Field experiments: Design, analysis, and interpretation. WW Norton. 
Gibson, James L. 2006. "Changes in American Veneration for the Rule of Law." DePaul L. Rev. 56:593.

Goldenziel, Jill. 2015. "When Law Migrates: Refugees in Comparative International Law.".

Golder, Matt. 2016. "Far right parties in Europe." Annual Review of Political Science 19:477-497.

Goodman, Ryan and Derek Jinks. 2004. "How to influence states: Socialization and international human rights law." Duke Law Journal pp. 621-703.

Goodwin-Gill, Guy S and Jane McAdam. 2007. The refugee in international law. Oxford University Press.

Guriev, Sergei and Daniel Treisman. 2015. "How modern dictators survive: Cooptation, censorship, propaganda, and repression.”.

Guzman, Andrew T. 2008. How international law works: a rational choice theory. Oxford University Press.

Hafner-Burton, Emilie M. 2013. Making Human Rights a Reality. Princeton, NJ: Princeton University Press.

Hainmueller, Jens and Daniel J Hopkins. 2014. "Public attitudes toward immigration." Annual Review of Political Science 17:225-249.

Hainmueller, Jens and Daniel J Hopkins. 2015. "The hidden American immigration consensus: A conjoint analysis of attitudes toward immigrants." American Journal of Political Science 59(3):529-548.

Hainmueller, Jens, Jonathan Mummolo and Yiqing Xu. 2017. "How much should we trust estimates from multiplicative interaction models? Simple tools to improve empirical practice.".

Helfer, Laurence R and Anne-Marie Slaughter. 1997. "Toward a theory of effective supranational adjudication." Yale lj 107:273.

Kaempfer, William H and Anton D Lowenberg. 1992. "Using threshold models to explain international relations." Public Choice 73(4):419-443.

Kehrberg, Jason E. 2007. "Public opinion on immigration in Western Europe: Economics, tolerance, and exposure." Comparative European Politics 5(3):264-281. 
Koh, Harold Hongju. 2003. “On American Exceptionalism.” Stanford Law Review pp. 1479-1527.

Kreps, Sarah E and Geoffrey PR Wallace. 2016. "International law, military effectiveness, and public support for drone strikes." Journal of Peace Research 53(6):830-844.

Kugler, Matthew B and Joel Cooper. 2010. "Still an american? mortality salience and treatment of suspected terrorists." Journal of Applied Social Psychology 40(12):3130-3147.

Kuran, Timur. 1997. Private truths, public lies: The social consequences of preference falsification. Harvard University Press.

Lin, Winston and Donald P Green. 2015. "Standard Operating Procedures: A Safety Net for Pre-Analysis Plans." Berkeley. Retrieved from www. stat. berkeley. edu/ winston/sop-safety-net. pdf(2014). Promoting transparency in social science research. Science (New York, NY) 343(6166):30-1.

Lin, Winston and Donald P Green. 2016. "Standard operating procedures: A safety net for pre-analysis plans." PS: Political Science \&amp; Politics 49(3):495-500.

Lupu, Yonatan. 2013. "The informative power of treaty commitment: using the spatial model to address selection effects." American Journal of Political Science 57(4):912-925.

Lupu, Yonatan. 2015. "Legislative veto players and the effects of international human rights agreements." American Journal of Political Science 59(3):578-594.

Lupu, Yonatan and Geoffrey PR Wallace. 2017. "Violence, Non-Violence, and the Effects of International Human Rights Law." unpublished manuscript .

MacWilliams, Matthew C. 2016. "Who decides when the party doesn't? Authoritarian voters and the rise of Donald Trump." PS: Political Science \& Politics 49(4):716-721.

Magaloni, Beatriz. 2006. "Voting for autocracy: Hegemonic party survival and its demise in Mexico.".

Martin, David A. 2007. Forced Migration: Law and Policy. West Academic.

Messina, Anthony M. 1989. Race and party competition in Britain. Oxford University Press, USA. 
Montgomery, Jacob M, Brendan Nyhan and Michelle Torres. 2016. How conditioning on post-treatment variables can ruin your experiment and what to do about it. In Annual meeting of the Midwest Political Science Association, Chicago, IL, April.

Morrow, James D. 2007. "When do states follow the laws of war?" American Political Science Review 101(3):559-572.

Morrow, James D. 2014. Order within anarchy: The laws of war as an international institution. Cambridge University Press.

Mudde, Cas. 2007. Populist radical right parties in Europe. Vol. 22 Cambridge University Press Cambridge.

Nyhan, Brendan and Jason Reifler. 2010. "When corrections fail: The persistence of political misperceptions." Political Behavior 32(2):303-330.

O'rourke, Kevin H and Richard Sinnott. 2006. "The determinants of individual attitudes towards immigration." European journal of political economy 22(4):838861.

Peffley, Mark and Jon Hurwitz. 2002. "The racial components of "race-neutral" crime policy attitudes." Political Psychology 23(1):59-75.

Pitterman, Shelly. 1985. "International responses to refugee situations: the United Nations High Commissioner for Refugees." Refugees and world politics pp. 4377.

Powell, Emilia Justyna. 2015. "Islamic law states and peaceful resolution of territorial disputes." International Organization 69(4):777-807.

Powell, Emilia Justyna and Sara McLaughlin Mitchell. 2007. "The International Court of Justice and the world's three legal systems." Journal of Politics 69(2):397-415.

Putnam, Tonya L and Jacob N Shapiro. 2017. "International Law and Voter Preferences: the Case of Foreign Human Rights Violations." Human Rights Review 18(3):243-262.

Rodman, Kenneth A. 1998. ““Think globally, punish locally”: nonstate actors, multinational corporations, and human rights sanctions." Ethics \& International Affairs 12:19-41. 
Saunders, Elizabeth. 2015. "The Political Origins of Elite Support for War: How Democratic Leaders Manage Public Opinion.”.

Scott, W Richard and John W Meyer. 1994. Institutional environments and organizations: Structural complexity and individualism. Sage.

Simmons, Beth A. 2009. Mobilizing for Human Rights: International Law in Domestic Politics. Cambridge University Press.

Sniderman, Paul M, Louk Hagendoorn and Markus Prior. 2004. "Predisposing factors and situational triggers: Exclusionary reactions to immigrant minorities." American political science review 98(1):35-49.

Tomz, Michael. 2008. "Reputation and the effect of international law on preferences and beliefs." Unpublished manuscript .

Wallace, Geoffrey PR. 2013. "International law and public attitudes toward torture: An experimental study." International Organization 67(1):105-140.

Wallace, Geoffrey PR. 2014. "Martial Law? Military experience, international law, and support for torture.” International Studies Quarterly 58(3):501-514.

Wilkes, Rima, Neil Guppy and Lily Farris. 2008. "“No thanks, we're full”: Individual characteristics, national context, and changing attitudes toward immigration." International Migration Review 42(2):302-329.

Wooldridge, Jeffrey M. 2010. Econometric Analysis of Cross-Sectional and Panel Data. 2nd edition ed. MIT Press.

Wright, Matthew, Morris Levy and Jack Citrin. 2016. "Public attitudes toward immigration policy across the legal/illegal divide: The role of categorical and attribute-based decision-making." Political Behavior 38(1):229-253. 